\title{
Najmenej rozvinuté okresy v Slovenskej republike \\ - problémy a riešenia
}

\section{The Least Developed Regions in the Slovak Republic \\ - Problems and Solutions}

\author{
Zuzana Hrabovská
}

https://doi.org/10.33542/VSS2020-1-05

\begin{abstract}
Regional development is currently becoming one of the key determinants contributing to the activation of local actors of regional development with a view to contributing to national economic development. For this reason, it is not desirable for the overall favourable development of the Slovak economy to exist or to deepen the differences in the economic performance of regions. The starting point for establishing a targeted set of support and development instruments is an active state approach to identifying problem regions and identifying key areas where targeted financial or non-financial support can be directed. The aim of this paper is to assess their impact on mitigating the negative economic and social impacts, which have been typical for these regions for several decades.
\end{abstract}

Key Words: least developed regions, regional disparities, action plan, Slovak Republic

\section{Úvod}

Ekonomicko-sociálny rozvoj v regiónoch Slovenskej republiky je dlhodobo charakteristický nerovnomerným vývojom a neustálym pretrvávaním medziregionálnych disparít $v$ kvalitatívnych a kvantitatívnych charakteristikách regiónov ako aj rozdielnosti v perspektívnych faktoroch rozvoja a konkurenčných výhod regiónov Slovenskej republiky. Existujúca (a v čase minimálne sa meniaca) rozdielnost' najmä ekonomickej výkonnosti regiónov, ktoré sú teritoriálne umiestnené v juhovýchodných okresoch Slovenskej republiky, predstavuje jeden z najzávažnejších problémov regionálneho rozvoja. Rozvoj regiónov sa v súčasnosti stáva jedným z klúčových determinantov, ktoré prispievajú k aktivizovaniu lokálnych aktérov regionálneho rozvoja so zámerom prispiet' $\mathrm{k}$ celonárodnému ekonomickému rozvoju. Z toho dôvodu nie je pre celkový priaznivý vývoj ekonomiky Slovenskej republiky žiaduce, aby existovali, prípadne sa d’alej prehlbovali rozdiely v ekonomickej výkonnosti regiónov. Jedným z hlavných ciel’ov regionálnej politiky je snaha o aplikáciu takých nástrojov, ktoré môžu prispiet' k zmierneniu existujúcich regionálnych rozdielov. Východiskom pre 
stanovenie cieleného súboru podporných a rozvojových nástrojov je aktívny prístup štátu k vymedzeniu problémových regiónov a identifikovaniu klúčových oblastí, do ktorých je možné smerovat' cielenú finančnú alebo nefinančnú podporu. Ciel'om predkladaného príspevku je na základe analýzy oblastí podpory a nástrojov použitých na podporu najmenej rozvinutých okresov v podmienkach Slovenskej republiky posúdit' ich vplyv na zmiernenie negatívnych ekonomicko-sociálnych vplyvov (súvisiacich najmä s negatívnym vývojom nezamestnanosti), ktoré sú pre tieto regióny typické už niekol'ko desat'ročí. Pri skúmaní aplikovaných nástrojov podpory na aktivizovanie rozvoja najmenej rozvinutých regiónov a zmiernenie existujúcich ekonomicko-sociálnych disparít predpokladáme existenciu závislosti objemu finančných prostriedkov na realizáciu nástrojov podpory a rastom zamestnanosti v týchto okresoch v Slovenskej republike.

\section{Historické súvislosti ekonomicko-sociálnej diferenciácie regiónov v SR}

Problémy súčasnej regionálnej diferenciácie regiónov Slovenska vyplývajú z viacerých negatívnych javov, ktoré sú dôsledkom vývoja spoločnosti a ekonomiky pred rokom 1989. Typické negatívne dôsledky ekonomických nástrojov v období rokov 1948 - 1989 sumarizuje Korec (2005, s. 35 - 37). Klúčovým faktorom ovplyvňujúcim negatívny ekonomický vývoj $\checkmark$ regiónoch bola nevyhovujúca odvetvová štruktúra priemyslu (dominujúce odvetvia boli energeticky vel'mi náročné, v roku 1990 Slovensko pokrývalo len 70\% svojej spotreby energie, spotreba energie na jednotku HDP bola na Slovensku trikrát vyššia ako v krajinách EÚ, ceny energie boli na Slovensku regulované štátom a boli výrazne nižšie ako v krajinách západnej Európy, t. j. existovala celková netransparentnost' cien výrobkov a konkurencieschopnosti priemyslu). Ďalšou problémovou oblast'ou bol nekvalifikovane riadený územný rozvoj priemysel, ktorý viedol k vzniku disproporcií medzi potenciálom regiónov a požiadavkami priemyslu (nedostatok pracovných síl v mieste lokalizácie priemyslu mal za následok vel'kú dochádzku do zamestnania, niektoré oblasti zostali z pohl'adu množstva pracovných síl priemyselne nerozvinuté, vel'ké disproporcie vznikli medzi primárnymi zdrojmi energie a miestami lokalizácie odvetví náročných na energiu). Na rozvoj priemyslu a vlastne celej regionálnej štruktúry Slovenska nepriaznivo vplývali aj niektoré nedostatky v organizácii a riadení priemyslu (100 \%-ným vlastníkom priemyslu bol štát - štátne podniky mali centrálne riadenie, existovala prezamestnanost' v priemysle - v roku 1989 v ňom pracovalo až $35 \%$ ekonomicky aktívneho obyvatel'stva, priemyselné podniky Slovenska pôsobili na umelom trhu krajín RVHP, neexistoval štandardný trhový mechanizmus, ktorý by prinútil priemysel k významnejšej transformácii. Okrem toho bolo extenzívnym rozvojom priemyslu narušené životné prostredie, čoho dôsledkom bolo znižovanie strednej dížky života, rast chorobnosti, poškodzovanie lesných porastov, zhoršenie kvality vôd v povrchových tokoch a d’alšie negatívne vplyvy. 
Jedným z najcharakteristickejších sprievodných javov spoločenskej a ekonomickej transformácie na Slovensku sa stal rýchly nárast regionálnych disparít $v$ ich potenciáloch, životných podmienkach i rozvojových disponibilitách atd'. Hlavným dôvodom vzniku a prehlbovania regionálnych rozdielov sú rozdielne možnosti regiónov prispôsobit' sa požiadavkám ekonomickej sociálnej transformácie, adaptovat' sa na nové rozvojové podmienky. Prejavuje sa tu aj odlišnost' štartovacích pozícií jednotlivých regiónov. Tieto rozdiely sú však podmienené komplexom dispozícií potenciálových (najmä ekonomických a l'udských zdrojov), infraštruktúrnych, civilizačno-kultúrnych, ale i polohových, ktoré zvyšujú, resp. redukujú ich rozvojové dispozície i atraktivitu (Gajdoš, 2005).

Za najvýznamnejší negatívny dôsledok vývoja regiónov pred rokom 1989 možno považovat' vznik tzv. regiónov chudoby, v ktorých sa ani po období transformácie nepodarilo aktivizovat' lokálnych aktérov podielajúcich sa na tvorbe nových pracovných miest v súlade s požiadavkami dopytu po pracovnej sile a v konečnom dôsledku s požiadavkou dopytu po produktoch, na výrobe ktorých by sa táto pracovná sila podiel'ala. $\mathrm{V}$ týchto problémových regiónoch sa koncentrujú problémy súvisiace s vysokou mierou nezamestnanosti, odchodom mladej a vzdelanej pracovnej sily mimo regiónu (starnutie obyvatel'stva a s tým spojené sociálne problémy) a nedostatkom investícií a podnikatel'ských aktivít. Z teritoriálneho hladiska sa tieto problémy dlhodobo koncentrujú v regiónoch na juhu a východe Slovenska. Priaznivejšia situácia je v regiónoch lokalizovaných v severozápadnej časti Slovenskej republiky.

Problematika existencie regionálnych disparít a nerovnomerného vývoja je široko diskutovanou témou aj v medzinárodnom kontexte. Nemožno opomenút' významný vplyv zaostávajúcich regiónov na úroveň celkovej regionálnej konkurencieschopnosti (Huggins, 2003). Úroveň konkurencieschopnosti je možné kvantifikovat' rôznymi spôsobmi (najčastejšie je skúmaná viackriteriálnymi modelmi), pričom viaceré medzinárodné štúdie považujú v tejto súvislosti za klúčové skúmanie absolútnych a relatívnych zmien hodnôt regionálneho hrubého domáceho produktu a rôznych ukazovatel'ov zamestnanosti resp. nezamestnanosti (Schubert, Turnovsky, 2017; Nikulin, 2015).

\section{Legislatívne vymedzenie postavenia najmenej rozvinutých okresov v SR}

Vychádzajúc z existujúcich hospodárskych rozdielov medzi okresmi a scielom aktivizovat' lokálnu ekonomiku v menej rozvinutých regiónoch bola v roku 2015 iniciovaná Úradom vlády SR legislatívna úprava (zákon č. 336/2015 Z. z. o podpore najmenej rozvinutých okresov a o zmene a doplnení niektorých zákonov) vo vzt'ahu k ekonomicko-sociálnym opatreniam, ktoré by umožnili cielene riešit' problémy menej rozvinutých regiónov. Podstatnou charakteristikou podpory najmenej rozvinutých okresov je spolupráca medzi vládou Slovenskej republiky, samosprávou a občianskou spoločnost'ou, vypracovaním pät'ročného Akčného 
plánu rozvoja najmenej rozvinutého okresu. Akčný plán môže nad rámec existujúcich opatrení a využívania existujúcich finančných zdrojov obsahovat' aj technickú podporu miestnej samospráve a občianskej spoločnosti a tzv. regionálny príspevok ako doplnkový zdroj financovania pri realizácii príslušného akčného plánu. (Úrad vlády SR, 2015)

Najmenej rozvinutý okres definuje $\S 2$ zákona č. 336/2015 Z. z. ako okres, ktorý je zapísaný v zozname najmenej rozvinutých okresov. Zoznam najmenej rozvinutých okresov vedie Ústredie práce, sociálnych vecí a rodiny SR, ktoré zapíše do zoznamu najmenej rozvinutých okresov okres, vktorom miera evidovanej nezamestnanosti vypočítaná z disponibilného počtu uchádzačov o zamestnanie, ktorú ústredie vykazuje, bola v období za aspoň devät' kalendárnych štvrt'rokov počas predchádzajúcich dvanástich po sebe nasledujúcich kalendárnych štvrt'rokov vyššia ako 1,6-násobok priemernej miery evidovanej nezamestnanosti v Slovenskej republike za rovnaké obdobie ( 3 ods. 3, pís. b) zákona 336/2015 Z. z.). V období do 1. mája 2018 boli do zoznamu najmenej rozvinutých okresov zapisované okresy, v ktorých miera evidovanej nezamestnanosti vypočítaná z disponibilného počtu uchádzačov o zamestnanie, ktorú ústredie vykazuje, bola za aspoň devät' kalendárnych štvrt'rokov od 1. apríla 2015 do 31. marca 2018 vyššia ako 1,5-násobok priemernej miery evidovanej nezamestnanosti v Slovenskej republike za rovnaké obdobie.

Udelením štatútu najmenej rozvinutého okresu vzniká takémuto okresu nárok na podporu, ktorej prijímatel'om sú subjekty územnej spolupráce a iné právnické osoby v súlade s Akčným plánom rozvoja najmenej rozvinutého okresu, ktoré sú uvedené v ročných prioritách akčného plánu. Prijímatel'om podpory v najmenej rozvinutom okrese môžu byt' aj fyzické osoby - podnikatelia.

Akčný plán je vládou Slovenskej republiky schválený záväzný dokument zameraný na odstraňovanie zaostávania najmenej rozvinutého okresu, ktorý vychádza zo základných dokumentov podpory regionálneho rozvoja, d’alších dokumentov a odporúčaní rady. (§ 4, ods. 1 zákona č. 336/2015 Z. z.)

Akčný plán možno považovat' za druh krátkodobého plánu regionálneho rozvoja regiónu, ktorého štruktúra zodpovedá štruktúre podobných plánovacích dokumentov (napr. Program hospodárskeho a sociálneho rozvoja). Akčný plán obsahuje analýzu nepriaznivého hospodárskeho, sociálneho a environmentálneho stavu najmenej rozvinutého okresu, zhodnotenie jeho rozvojového potenciálu, návrh opatrení a úloh na zabezpečenie realizácie a plnenia akčného plánu, časový harmonogram, spôsoby a zdroje financovania, monitorovanie a hodnotenie dosiahnutého pokroku. Akčný plán zároveň integruje už existujúce rezortné programy, prierezové programy a obsahuje návrhy na odstránenie prekážok na ich využívanie. Návrh akčného plánu predkladá rada úradu vlády do šiestich mesiacov od zápisu okresu do zoznamu najmenej rozvinutých okresov. Návrh akčného plánu 
po pripomienkovom konaní predkladá úrad vlády vláde. Akčný plán sa vypracováva spravidla na obdobie piatich rokov a realizuje sa prostredníctvom ročných priorít.

Okrem akčného plánu sa pre každý akčný plán najmenej rozvinutého okresu vypracúvajú tzv. ročné priority, ktoré sú vládou schválený záväzný dokument zameraný na realizáciu ciel'ov akčného plánu v príslušnom roku realizácie akčného plánu a vypracúvajú sa na kalendárny rok.

Podpora sa poskytuje $v$ súlade $s$ akčným plánom a ročnými prioritami $v$ súlade s osobitnými predpismi, zákonom o štátnom rozpočte na príslušný rozpočtový rok (§ 6 - 8, zákona č. 336/2015 Z. z.) vo forme technickej podpory (odovzdávaní znalostí, skúseností a transfer špecifického know-how) a regionálneho príspevku, ktorý je finančným príspevkom poskytovaným $z$ rozpočtovej kapitoly úradu vlády $v$ súlade $s$ akčným plánom a ročnými prioritami.

Zákon č. 336/2015 Z. z. o podpore najmenej rozvinutých okresov nadobudol účinnost' 15. decembra 2015. K tomuto dátumu boli zaradené medzi najmenej rozvinuté okresy zaradených prvých 12 okresov (Tabul'ka 1).

Tabul'ka 1: Najmenej rozvinuté okresy v SR k 31. 03. 2020

\begin{tabular}{|c|c|c|c|c|c|c|}
\hline okres & $\begin{array}{c}\text { zaradený } \\
\text { medzi } \\
\text { najmenej } \\
\text { rozvinuté } \\
\text { okresy }\end{array}$ & $\begin{array}{l}\text { schválený } \\
\text { akčný plán }\end{array}$ & $\begin{array}{c}\text { počet } \\
\text { obyvatel'ov* }\end{array}$ & $\begin{array}{c}\text { miera } \\
\text { nezamest- } \\
\text { nanosti }^{\star}\end{array}$ & $\begin{array}{l}\text { vytvorené } \\
\text { pracovné } \\
\text { miesta } \\
\text { (plán) }\end{array}$ & $\begin{array}{l}\text { odhadovaný } \\
\text { rozpočet } \\
\text { (plán) }\end{array}$ \\
\hline Kežmarok & 15.12 .2015 & 10.2 .2016 & 73756 & 19,90 & 2000 & 52000000 \\
\hline Rimavská Sobota & 15.12 .2015 & 24.6 .2016 & 84518 & 24,20 & 2300 & 157000000 \\
\hline Lučenec & 15.12 .2015 & 26.6 .2016 & 74016 & 13,93 & 1440 & 147324000 \\
\hline Sabinov & 15.12 .2015 & 22.8 .2016 & 59694 & 15,80 & 1115 & 79797000 \\
\hline Sobrance & 15.12 .2015 & 23.8 .2016 & 22818 & 15,67 & 1225 & 69000000 \\
\hline Trebišov & 15.12 .2015 & 24.8 .2016 & 105797 & 16,42 & 1540 & 114426000 \\
\hline $\begin{array}{l}\text { Vranov nad } \\
\text { Topl'ou }\end{array}$ & 15.12 .2015 & 30.8 .2016 & 80497 & 17,00 & 2545 & 123000000 \\
\hline Svidník & 15.12 .2015 & 31.8 .2016 & 38845 & 17,27 & 1418 & 63000000 \\
\hline Poltár & 15.12 .2015 & 7.9 .2016 & 21767 & 17,15 & 750 & 98584000 \\
\hline Vel'ký Krtíš & 15.12 .2015 & 7.9 .2016 & 44212 & 13,37 & 822 & 75000000 \\
\hline Revúca & 15.12 .2015 & 13.9 .2016 & 40052 & 21,86 & 1100 & 61000000 \\
\hline Rožňava & 15.12 .2015 & 14.9 .2016 & 62515 & 20,18 & 1345 & 108914000 \\
\hline Gelnica & 30.6 .2017 & 5.4 .2018 & 31627 & 13,12 & 931 & 55749100 \\
\hline Bardejov & 30.9 .2017 & 4.7 .2018 & 77742 & 12,23 & 1370 & 169026683 \\
\hline Medzilaborce & 30.9 .2017 & 7.7 .2018 & 12119 & 13,41 & 377 & 38554000 \\
\hline Košice - okolie & 22.1 .2018 & 3.10 .2018 & 125289 & 12,12 & 822 & 71430000 \\
\hline Snina & 25.4 .2018 & 16.1.2019 & 36610 & 8,10 & 582 & 76103000 \\
\hline Levoča & 25.4 .2018 & 17.1.2019 & 33668 & 9,10 & 515 & 34203000 \\
\hline Stropkov & 19.10 .2018 & 25.6 .2019 & 20623 & 8,57 & 261 & 73855800 \\
\hline Michalovce & 19.10 .2018 & 26.6 .2019 & 110713 & 10,10 & 824 & 91415000 \\
\hline Spolu & & & 1156878 & & 23282 & 1759381583 \\
\hline
\end{tabular}

Zdroj: vlastné spracovanie podla údajov Úradu podpredsedu vlády SR pre investície a informatizáciu (cit. 31. 03. 2020)

Poznámka: *údaje ku dňu zaradenia medzi najmenej rozvinuté okresy 
K 31. 03. 2020 je Ústredím práce, sociálnych vecí a rodiny SR evidovaných celkom 20 okresov, ktorých teritoriálne rozmiestnenie znázorňuje Graf 1.

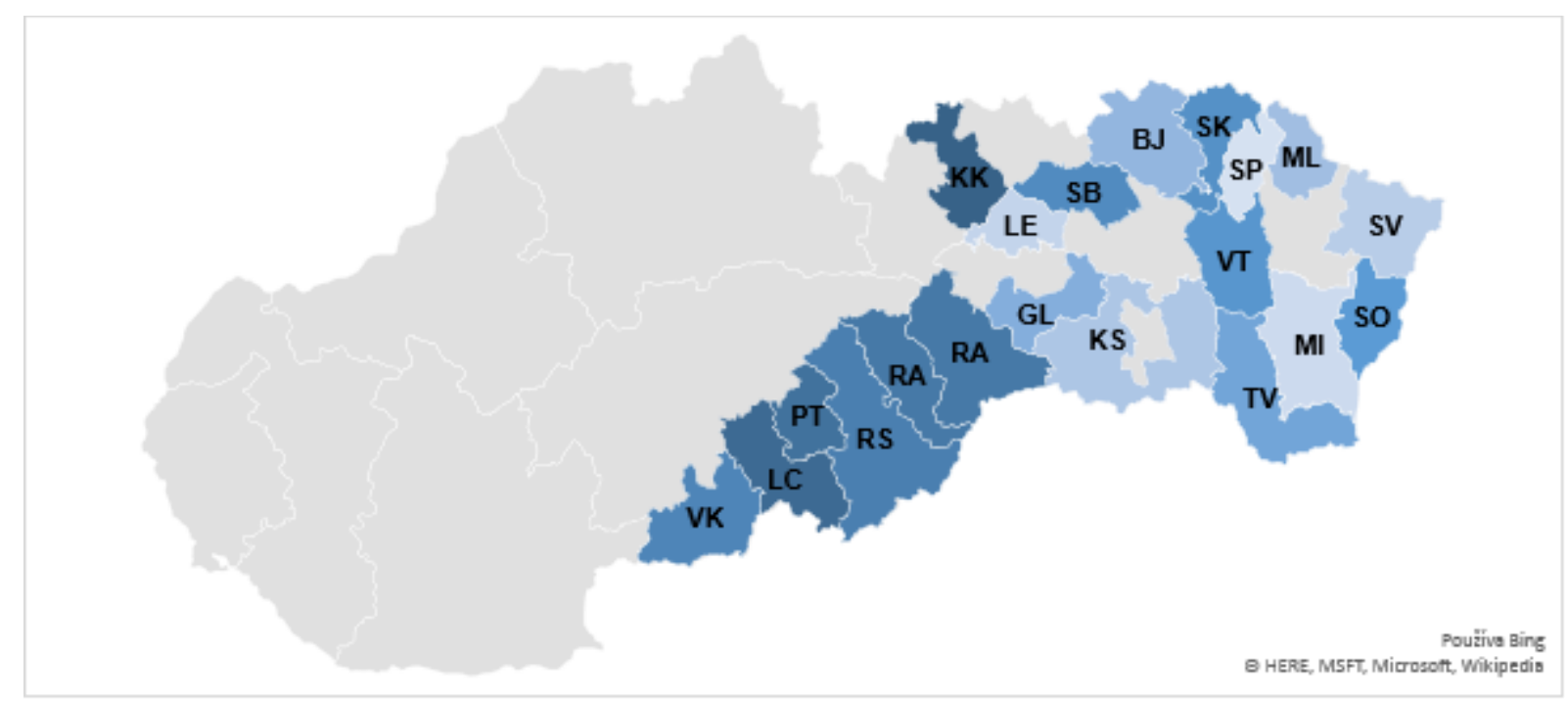

Graf 1: Najmenej rozvinuté okresy v SR k 31. 03. 2020

Zdroj: vlastné spracovanie

Rozmiestnenie najmenej rozvinutých okresov na území Slovenskej republiky potvrdzuje, že problémy nepriaznivého ekonomicko-sociálneho vývoja pretrvávajú v okresoch, ktoré sú lokalizované v juhovýchodnej časti krajiny.

\section{Ekonomicko-sociálne problémy najmenej rozvinutých okresov v SR}

Najmenej rozvinuté okresy $v S R$ sú charakteristické kumulatívnym výskytom hospodárskych, sociálnych a environmentálnych problémov.

Najvýraznejšími sú hospodárske problémy, ktoré vznikajú ako dôsledok rastu nezamestnanosti. Za negatívny jav možno v tejto súvislosti považovat' najmä dlhodobú vysokú úroveň nezamestnanosti $v$ najmenej rozvinutých regiónoch. Hlavné dôsledky neriešenia problematiky nezamestnanosti sú pre región strata nevyužitého vzácneho výrobného zdroja, nižšie úspory obyvatel'stva, nižšia tvorba produktu, ale aj nižšiu spotreba v dôsledku nižších disponibilných príjmov a pokles životnej úrovne obyvatel'stva. Nemenej dôležité je skúmanie sociologických aspektov nezamestnanosti ako je skupina problémov súvisiaca so sociálne vylúčenými skupinami obyvatel'stva, či negatívnymi osobnými a spoločenskými dôsledkami poklesu kvality života obyvatel'ov. Aj Gajdoš (2005, s. 116 - 118) považuje nezamestnanost' za negatívny jav $v$ menej rozvinutých regiónoch, pretože tieto regióny sú negatívne ovplyvnené nielen štrukturálnymi zmenami, ale i nízkou vzdelanostnou úrovňou a značnou sociálnou marginalizáciou a sú charakteristické i prostredím, ktoré vytvára špecifickú etnickú kultúru a sociálnu izoláciu od sociálnych sietí hlavného prúdu spoločnosti. 
Pre mnohé z najmenej rozvinutých okresov je typický pokles počtu obyvatel'ov v produktívnom veku pri súčasnom náraste počtu obyvatel'ov poproduktívneho veku (typické pre okresy Vel'ký Krtíš, Poltár, Lučenec, Revúca). Pokles počtu obyvatel'ov v produktívnom veku je v okresoch Trebišov, Kežmarok, Rimavská Sobota kompenzovaný dynamickejším rastom počtu obyvatel'ov v predproduktívnom veku (s nárastom najmä v skupine obyvatel'ov rómskej národnosti). Osobitnú skupinu okresov tvoria okresy, vktorých je typický trend vyludňovania a prudkého poklesu počtu obyvatel'ov vo všetkých vekových kategóriách (napr. okres Medzilaborce a Sobrance).

Z pohl'adu hospodárskej štruktúry sú menej rozvinuté okresy orientované skôr na pol'nohospodársku výrobu s nízkym podielom priemyselných podnikov. Dôvodom je horšia dopravná dostupnost' $\mathrm{k}$ subdodávatel'om a ciel'ovým trhom, preto sa v menej rozvinutých regiónoch rozvíjajú skôr lokálne typické podnikatel'ské aktivity zamerané na odevnú, strojársku, drevársku, kožiarsku alebo inú spracovatel'skú produkciu.

Problematickou je v menej rozvinutých okresoch aj oblast' školstva. Počet žiakov základných a stredných škôl klesá. Okrem nesúladu kapacít škôl a školských zariadení je oblast' školstva charakteristická aj nesúladom ponúkaných stredoškolských profesií v súlade s očakávaniami trhu práce. Najžiadanejšie študijné a učebné odbory sú remeselného charakteru - manipulačný pracovník, administratívny pracovník, predavač, murár, šička, kuchár, učitel', zvárač, pričom záujem uchádzačov je skôr o všeobecné stredoškolské vzdelanie s ambíciou pokračovat' vo vysokoškolskom štúdiu.

Dôsledkom rastu počtu obyvatel'ov v poproduktívnom veku je potreba zvyšovania kapacít rôznych druhov sociálnych zariadení (útulky, domovy na polceste, denné stacionáre, zariadenia sociálnych služieb a pod.) a tiež sa zvyšuje dopyt po dostupnej zdravotnej starostlivosti, ktorá je v odlahlých regiónoch často problematicky realizovatel'ná.

Nemenej dôležitou oblast'ou je z pohl'adu celkového vnímania kvality života na určitom území aj oblast' kvality a ochrany životného prostredia. Najmenej rozvinuté regióny sa aj v dôsledku nižšej koncentrácie vel'kých priemyselných podnikov (ktoré sú často značnými znečist'ovatel'mi životného prostredia) vyznačujú kvalitnejším a menej znečisteným životným prostredím.

\section{Perspektívy a možnosti riešenia problémov najmenej rozvinutých okresov v SR}

Napriek mnohým vyššie načrtnutým problémom, disponujú najmenej rozvinuté okresy v SR rozvojovým potenciálom, ktorý je využitel'ný na zníženie miery nezamestnanosti a zvýšeniu kvality života obyvatel'ov v týchto regiónoch.

Správny rozvoj regiónu v rámci zamestnanosti môžeme dosiahnut' správnym uplatnením regionálnej politiky zamestnanosti, ktorá napomáha pri odstraňovaní regionálnych 
disparít. Neustále vysokú mieru nezamestnanosti na Slovensku sprevádza nielen regionálna koncentrácia medzi okresmi a v ich rámci aj vekové odlišnosti, ale aj rastúca náchylnost' na nezamestnanost', spôsobená úrovňou kvalifikácie, ktorá je ovplyvnená viacerými sociálnymi faktormi. Regionálna politika zamestnanosti je zameraná na dlhodobo strategické investovanie do vzdelania a do profesií, poradenstva, ktoré sú potrebné pre trh práce v súčasnosti i pre trh práce $v$ blízkej budúcnosti.

Pri riešení problémov $v$ oblasti nezamestnanosti najmenej rozvinutých regiónov je možné využit' existenciu prosperujúcich podnikov s dobrou pozíciou na svetových trhoch, existenciu predpokladov pre rozvoj pol'nohospodárskej výroby, vysoký potenciál stredného odborného školstva, výhodné cezhraničné prepojenie a rozvinutá cezhraničná spolupráca samospráv, spolupráca $v$ oblasti práce, kultúry, turistiky, ochrany prírody, spoločenských kontaktov a pod., ako aj možnost' využitia potenciálu hospodárskych lesov a lepšieho zhodnotenia drevnej hmoty.

Vychádzajúc z identifikovaných problémových oblastí a oblastí rozvojového potenciálu najmenej rozvinutých okresov sú $v$ akčných plánoch jednotlivých okresov formulované opatrenia a aktivity, ktorých realizácia má prispiet' k naplneniu stanovených ciel'ov $v$ oblasti hospodárskeho, sociálneho a environmentálneho rozvoja týchto okresov.

Opatrenia a aktivity sú pre všetky najmenej rozvinuté regióny formulované v akčných plánoch $v$ týchto oblastiach:

$A$ - Systémové opatrenia - vytvorenie kapacít, inštitucionálnych a organizačných rámcov a zabezpečenie logistickej a technickej podpory na implementáciu Akčného plánu ( $\mathrm{v}$ rámci tohto opatrenia vznikli v najmenej rozvinutých okresoch Centrá podpory regionálneho rozvoja okresu ako administratívne centrá, ktoré slúžia na sprostredkovanie žiadosti o poskytnutie regionálneho príspevku pre fyzické a právnické osoby),

$B$ - Podnikanie a viac pracovných miest - podpora miestnej ekonomiky a inovácií, za účelom zvyšovania zamestnanosti intervenciami na dopytovej strane trhu práce. Výsledkom by mal byt' rozvoj ekonomických aktivít podnikatel'ského a verejného sektora, ktoré zhodnocujú lokálne zdroje a umožňujú využitie disponibilnej pracovnej sily (príkladom je podpora podnikatel'ských aktivít v pol'nohospodárstve a nadväzujúcich odvetviach, podpora subjektov sociálnej ekonomiky, vznik tréningových centier na prípravu pracovnej sily).

C - Vzdelávanie, flexibilita a kariéra - zlepšenie kvality a dostupnosti vzdelávania s dôrazom na modernizáciu existujúcej vzdelávacej infraštruktúry a zvýšenie schopnosti siete vzdelávacích inštitúcii flexibilne reagovat' na meniace sa potreby trhu práce a špecifické potreby miestnej ekonomiky (napr. opatrenia na zlepšenia postavenia uchádzačov o zamestnanie na trhu práce, s ciel'om zvýšit' ich zamestnatel'nost', znížit' predovšetkým dlhodobú nezamestnanost'). 
$D$ - Moderné a dostupné verejné služby - riešenie otázky vysokej migrácie osôb najmä v produktívnom veku, nedostatku zdravotníckych a iných sociálnych zariadení, otázky bývania pre znevýhodnených či nedostatočnej technickej infraštruktúry.

E - Udržatel'ná mobilita pracovnej sily - podpora budovania účelových cyklotrás, zlepšenie prístupu priemyselných parkov a priemyselných zón na nadradenú dopravnú infraštruktúru.

F - Systémové opatrenia na úrovni samosprávneho kraja - zriadenie krajských centier regionálneho rozvoja pre koordináciu, podporu a monitorovanie regionálneho rozvoja $v$ najmenej rozvinutých okresoch kraja, prehodnotenie možností a zmien nastavenia systému stredného školstva so zameraním na potreby trhu práce.

Ciel'om vyššie uvedených opatrení, ktoré sú jednotlivo konkretizované v akčných plánoch najmenej rozvinutých regiónov, je zamedzenie d’alšiemu prehlbovaniu hospodárskych, sociálnych a environmentálnych problémov a zmiernenie dopadov ekonomického zaostávania týchto regiónov v porovnaní s vyspelejšími regiónmi v Slovenskej republike. Očakávaným pozitívnym efektom opatrení, ktorých realizáciu predpokladajú akčné plány je aj rast počtu novovytvorených pracovných miest. Celkovo by po úspešnom realizovaní všetkých opatrení formulovaných v akčných plánoch najmenej rozvinutých okresov malo byt' vytvorených 23282 pracovných miest a vo forme finančného príspevku resp. technickej pomoci by malo byt' rozdelených 1759381583 EUR (Tabul'ka 1.)

Analýzou plánovaných veličín uvedených v Akčných plánoch najmenej rozvinutých regiónov v SR sme zistili, že najmenší počet pracovných miest v prepočte na počet obyvatel'ov sa plánuje vytvorit' $v$ okrese Košice okolie a Michalovce. $V$ týchto okresoch pripadá na 1 novo vytvorené pracovné miesto až 152,42 resp. 134,36 obyvatel'ov okresu. Najpriaznivejšia situácia, teda najväčšia šanca získat' nové pracovné miesto je v okresoch Sobrance, Svidník a Poltár, v ktorých sa očakáva zamestnanie každého najviac 30 . obyvatel'a okresu (Graf 2). 


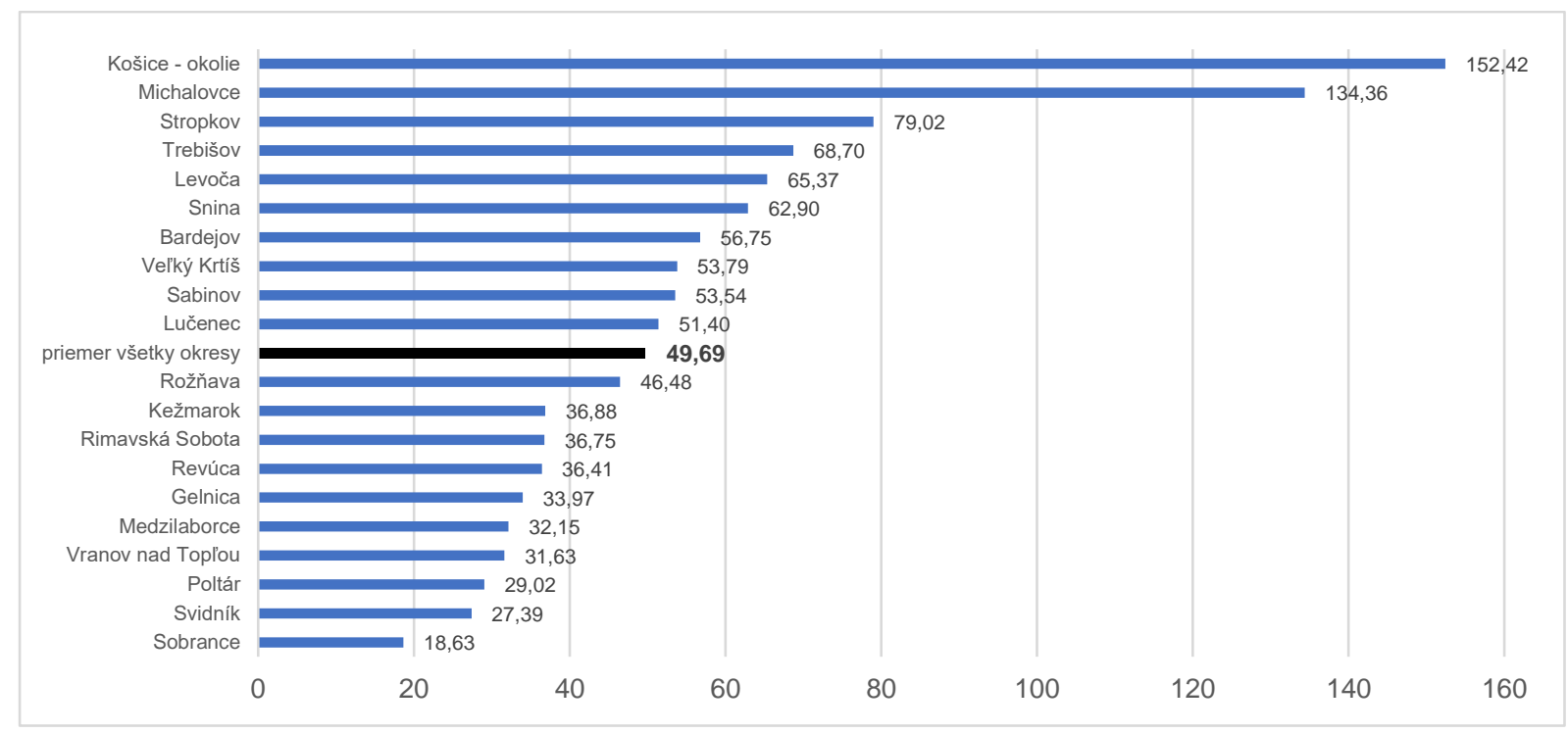

\section{Graf 2: počet obyvatel'ov najmenej rozvinutých okresov SR pripadajúcich na jedno} vytvorené pracovné miesto

Zdroj: vlastné spracovanie na základe Akčných plánov najmenej rozvinutých regiónov

Priemerný objem prostriedkov odhadovaných v rozpočtoch akčných plánov na realizované aktivity je v celkovom objeme 1759381583 EUR. Na jedného obyvatel'a všetkých dvadsiatich najmenej rozvinutých okresov pripadá v priemere 1520, 80 EUR. Najväčší objem finančných prostriedkov je plánovaných pre okresy Poltár, Stropkov, Medzilaborce a Sobrance (Graf 3). V týchto okresoch pripadá na jedného obyvatela okresu až viac ako 3000 EUR celkovej plánovanej sumy na podporu hospodárskeho a sociálneho rozvoja okresu. Najnižší podiel vynaložených prostriedkov na obyvatel'a je plánované vokresoch Košice okolie, Kežmarok a Michalovce. $V$ týchto okresoch je plánovaná výška finančných prostriedkov na aktivizáciu ekonomického rozvoja v okrese nižšia ako 1000 EUR.

Pri skúmaní toho, kol'ko plánovaných prostriedkov má byt' vynaložených na jedno pracovné miesto (Graf 4) zist'ujeme, že finančne najnáročnejšie je vytvorenie pracovných miest v okrese Stropkov (282 972 EUR), Poltár (131 445 EUR) a Snina (130 761 EUR). 


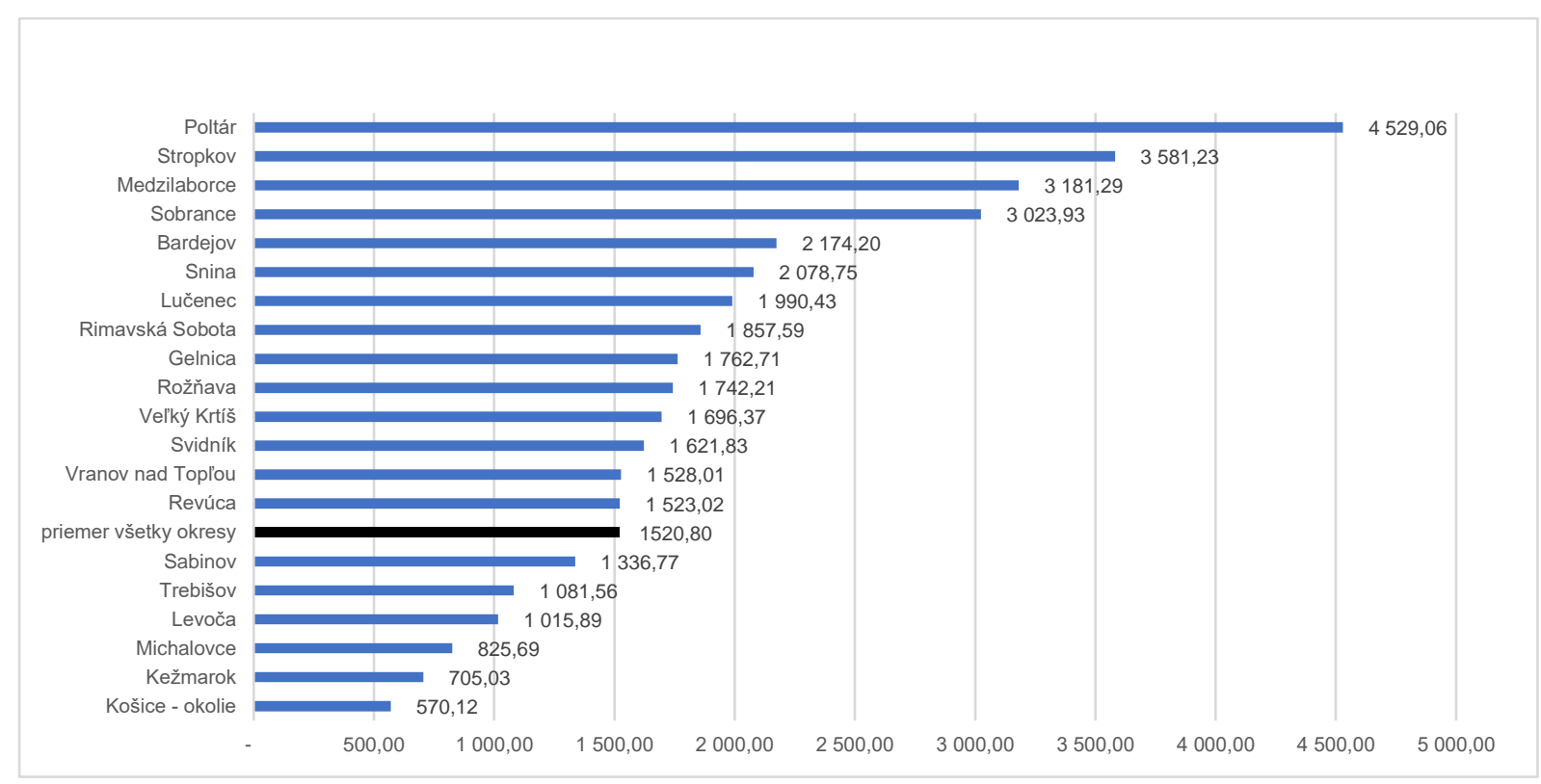

Graf 3: Plánovaný objem investícií v EUR na 1obyvatel’a najmenej rozvinutého okresu SR

Zdroj: vlastné spracovanie na základe Akčných plánov najmenej rozvinutých regiónov

Za hlavný dôvod vzniku a prehlbovania regionálnych rozdielov možno považovat' rozdielne možnosti regiónov prispôsobit' sa požiadavkám ekonomickej a sociálnej transformácie, rozdielne faktory konkurencieschopnosti a d'alšieho rozvoja, dlhodobo neriešené a pretrvávajúce činitele podmieňujúce regionálnu diferenciáciu. Okrem toho možno za limitujúce faktory priaznivého rozvoja regiónov považovat' aj schopnost' adaptovat' sa na nové podmienky, úroveň efektivity verejnej správy, resp. funkčný legislatívny, inštitucionálny či administratívny rámec regionálnej politiky. 


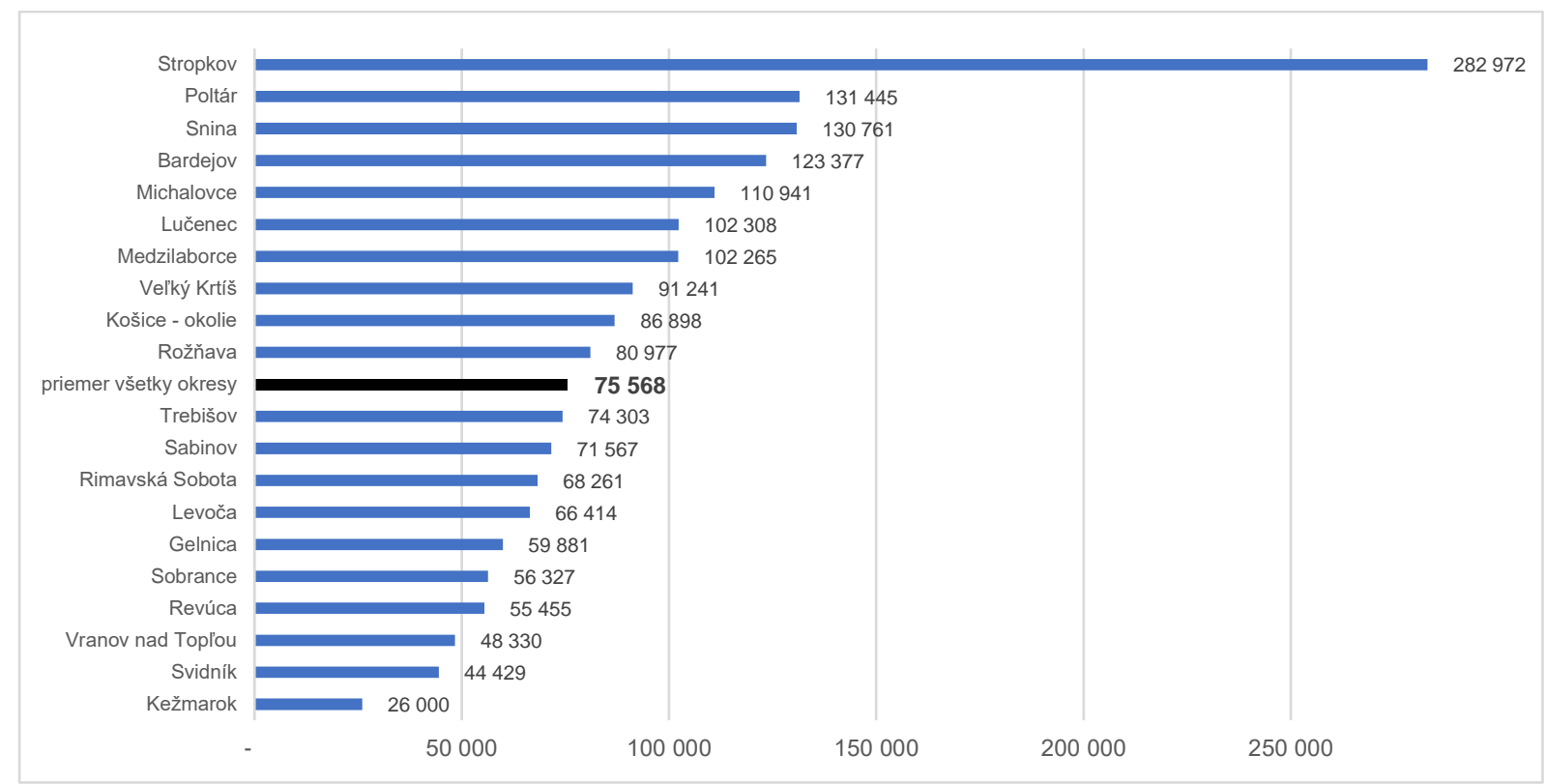

Graf 4: Plánovaný objem EUR na 1 vytvorené pracovné miesto v najmenej rozvinutých okresoch SR

Zdroj: vlastné spracovanie na základe Akčných plánov najmenej rozvinutých regiónov

Správny rozvoj regiónu v rámci zamestnanosti môžeme dosiahnut' správnym uplatnením regionálnej politiky zamestnanosti, ktorá napomáha pri odstraňovaní regionálnych disparít. Neustále vysokú mieru nezamestnanosti na Slovensku sprevádza nielen regionálna koncentrácia medzi okresmi a v ich rámci aj vekové odlišnosti, ale aj rastúca náchylnost' na nezamestnanost', spôsobená úrovňou kvalifikácie, ktorá ustavične koreluje s celou škálou sociálnych faktorov. Pri tvorbe regionálnej politiky zamestnanosti by nemala absentovat' ani problematika rozvoja l'udských zdrojov, ktorá by mala byt' prepojená na opatrenia zamerané na podporu zlepšenia zamestnatel'nosti ludí na regionálnom trhu práce a na podporu adaptability podnikov a ich zamestnancov. Regionálna politika zamestnanosti je zameraná na dlhodobo strategické investovanie do vzdelania a do profesií, poradenstva, ktoré sú potrebné pre trh práce $v$ súčasnosti i pre trh práce $v$ blízkej budúcnosti.

\section{Záver}

Najmenej rozvinuté regióny v Slovenskej republike sú regiónmi, v ktorých sa dlhodobo kumulujú problémy súvisiace najmä s nerovnomerným hospodárskym rozvojom, pričom $v$ týchto regiónoch dlhodobo nezaznamenávame významné pozitívne zmeny, ktoré by viedli k postupnému zmierňovaniu regionálnych disparít, ktoré ostávajú (a zdá sa, že tento trend bude pretrvávat' aj v budúcnosti) na rovnakej úrovni ako v posttransformačnom období v 90ych rokoch 20. storočia. Jedným z ciel'ov regionálneho rozvoja je zvyšovanie zamestnanosti ako klúčového faktora ovplyvňujúceho nielen rast hodnoty regionálneho hrubého domáceho 
produktu, ale aj významného činitel'a ovplyvňujúceho kvalitu života obyvatel'ov jednotlivých regiónov. Slovenský trh práce nie je homogénny, pozostáva z viacerých regionálnych trhov práce $s$ vlastnými špecifikami a dynamikou. Regionálna nezamestnanost' je dôsledkom a súčasne prejavom nerovnováhy na regionálnom trhu práce, medzi ponukou a dopytom po práci. Preto považujeme za nevyhnutné venovat' pozornost' cielenej podpore regiónov so špecifickými problémami, ktoré znevýhodňujú najmenej rozvinuté regióny v porovnaní s vyspelejšími regiónmi. Predkladaný príspevok je analýzou podpory najmenej rozvinutých regiónov v období od nadobudnutia účinnosti zákona o podpore najmenej rozvinutých okresov v Slovenskej republike v decembri 2015 do 31. marca 2020. Podpora najmenej rozvinutých okresov má zásadný význam pri napínaní dlhodobých strategických ciel'ov rozvoja krajiny, preto vyjadrujeme presvedčenie, že aj v budúcnosti budú realizované finančné a nefinančné opatrenia s ciel'om postupného zmierňovania ekonomicko-sociálnych problémov najmenej rozvinutých okresov v Slovenskej republike.

\section{Pod'akovanie}

Príspevok je čiastkovým výstupom riešenia grantovej úlohy VEGA 1/0153/18 "Evaluácia výkonnosti regionálnej samosprávy $v$ kontexte jej vplyvu na ekonomické a sociálne faktory rozvoja regiónov v Slovenskej republike“.

\section{Literatúra}

GAJDOŠ, P. 2005. Diferenciácia regionálneho rozvoja Slovenska a jej sociálno-priestorové súvislosti a dopady. [online] [cit. 2020-03-25]. Dostupné z: http://www.cers.tuke.sk/cers2005/doc/Gajdos.

HRABOVSKÁ, Z. 2012. Miera nezamestnanosti samosprávnych krajov v Slovenskej republike ako indikátor hodnotenia úrovne regionálneho rozvoja. Manažment podnikania a vecí verejných : zborník vedeckých prác. Bratislava : ALDO, roč. II., č. 2 (2012), s. 357-362. ISBN 978-80-970-7592-7.

HUGGINS, R. 2003. Creating a UK Competitiveness Index: Regional and Local Benchmarking. Regional Studies, 37 (1), 89 - 96.

KOREC, P. 2005. Regionálny rozvoj Slovenska v rokoch 1989-2004. Bratislava: Geografika. ISBN 80-969338-0-9.

NIKULIN, D. 2015. Relationship between wages, labour productivity and unemployment rate in new EU member countries. Journal of International Studies, 1, 31-40. doi:10.14254/2071$8330.2015 / 8-1 / 3$

SCHUBERT, S. F., TURNOVSKY, S. J. 2017. Growth and unemployment: Short-run and longrun tradeoffs. Journal of Economic Dynamics \& Control, doi:10.1016/j.jedc.2017.11.003 ÚRAD PODPREDSEDU VLÁDY SR PRE INVESTÍCIE A INFORMATIZÁCIU. 2020. Podpora najmenej rozvinutých okresov a regionálny rozvoj. Akčné plány rozvoja najmenej rozvinutých okresov v SR. [online] [cit. 2020-03-28].

Dostupné z: https://www.nro.vicepremier.gov.sk/index.html 
ÚRAD VLÁDY SR. 2015 Dôvodová správa k návrhu zákona o podpore najmenej rozvinutých okresov a o zmene a doplnení zákona č. $561 / 2007$ z. z. o investičnej pomoci a o zmene a doplnení niektorých zákonov $v$ znení neskorších predpisov. [online] [cit. 2020-03-25]. Dostupné z: https://rokovania.gov.sk/RVL/Material/12268/1

Zákon č. 539/2008 Z. z. o podpore regionálneho rozvoja

Zákon č. 336/2015 Z. Z. o podpore najmenej rozvinutých okresov a o zmene a doplnení niektorých zákonov

\section{Adresa autorky}

Ing. Zuzana Hrabovská, PhD.

Univerzita Pavla Jozefa Šafárika v Košiciach

Fakulta verejnej správy

Katedra ekonomiky a riadenia verejnej správy

Popradská 66

04132 Košice 1

E-mail: zuzana.hrabovska1@upjs.sk 